\title{
EFFECT OF RIDGE SPACING AND IRRIGATION PATTERNS ON GROWTH, GRAIN YIELD, YIELD COMPONENTS, AND WATER PRODUCTIVITY FOR MAIZE CROP \\ Mahgoub, G. M. A. ${ }^{1}$; M. M. A. Osman'; H. H. Abdel-Maksoud ${ }^{2}$ and Hoda Kh. A. El-Mekser ${ }^{1}$ \\ 1- Maize Res. Dept., Field Crops Res. Inst., Agric. Res. Center. \\ 2- Water Requirements and Field Irrigation Res. Dept., Soils and Water Res. Inst., Agric. Res. Center.
}

\begin{abstract}
A Field trial was conducted in Gemmeiza Agricultural Research Station (Middle Nile Delta, Egypt) in 2011and 2012 to study the effect of four irrigation patterns under two ridge spacing on maize growth, grain yield, yield components, saving of applied irrigation water, and water productivity(WP). The assessed irrigation patterns were: 1) Control where all of furrows were irrigated (ALL), 2) irrigating via every other furrow starting at the $3^{\text {rd }}$ irrigation (EOF3), 3) irrigation via every other furrow technique starting from the $4^{\text {th }}$ irrigation (EOF4), and 4 ) irrigating with every other furrow starting from the $5^{\text {th }}$ irrigation (EOF5). Irrigation patterns were evaluated under two ridge spacing $(70$ and $80 \mathrm{~cm})$. The experimental design was randomized complete block arranged in incomplete block design, where replications were nested within ridge spacing and irrigation pattern treatments were randomly arranged within ridge spacing treatments.

The most important findings could be as follows:-

*Under $80-\mathrm{cm}$ ridge spacing both days to $50 \%$ tasseling and $50 \%$ silking were significantly decreased, but $70-\mathrm{cm}$ ridge spacing reduced ear height, and ear position (\%).

* Ridge spacing did not significantly affect plant height, grain yield, number of kernels per row, ear length, ear diameter, kernel depth, and 100-kernel weight. However, 80-cm ridge spacing was associated with higher ear length, ear diameter, kernel depth, and 100-kernel weight.

*Irrigation pattern (EOF3) had significantly higher days to $50 \%$ tasseling than the control (ALL). Treatment EOF4 had the highest plant height. The lowest plant height was linked to EOF5 treatment but the highest ear height and ear position resulted from application of EOF3.

*Grain yield was not significantly affected by irrigation patterns. Irrigation patterns EOF4 and EOF5 were associated with the lowest number of kernels per row.

* Effect of ridge spacing $x$ irrigation pattern Interaction was significant for plant height, ear height and kernel depth.

*Applied irrigation water decreased, while water productivity increased under $80-\mathrm{cm}$ comparing with $70-\mathrm{cm}$ ridge spacing. The highest value of applied water was recorded for $(A L L)$ irrigation pattern treatment with $70-\mathrm{cm}$ ridge spacing. Application of EOF3, EOF4, and EOF5 patterns reduced applied irrigation water and improved water productivity.

*The highest WP was recorded under the interaction of planting maize crop in 80-cm ridge spacing with EOF3 and EOF4 irrigation patterns. Saving irrigation water was higher at EOF3 followed by EOF4, then EOF5. This study strongly suggest applying every other furrow irrigation technique starting from the $3^{\text {rd }}$ irrigation
\end{abstract}


(EOF3) with planting maize crop on $80-\mathrm{cm}$ ridge spacing to save more irrigation water without concomitant reduction in grain yield.

Keywords: maize, grain yield, yield components, ridge spacing, every other furrow irrigation, water productivity.

\section{INTRODUCTION}

In Egypt, under furrow irrigation, maize crop normaly needs to apply seven to eight or more irrigations throughout the growing season, depending on duration of genotype maturity, location, prevailing weather conditions, and soil texture.......etc. Water losses under surface irrigation is mainly due to deep percolation, particularly in the upper part of the field that comprise not less than $45 \%$, causing several acute problems i.e. nutrient leaching and raising groundwater, which consequently negatively affected grain yield and reduce fertilizer and water use efficiencies. Therefore, improving performance of the surface irrigation method is must, particularly under limited irrigation water resources. Abdel-Maksoud and Khater (1997) reported that irrigation of every other furrow was linked to reduction in both maize yield by $7.22 \%$ and water applied by $21.1 \%$, comparable with the traditional furrow irrigation. Furthermore, Mahgoub et al. (2009) stated that every other furrow irrigation saved 8.43 and $9.36 \%$ of applied irrigation water for maize plants grown on 70 and $80-\mathrm{cm}$ ridges, respectively, comparable with the control. In connection, Shayannejad and Moharrery (2009) stated that every other furrow irrigation reduced the volume of irrigation water and improved water use efficiency. Rafiee and Shakarami (2010) found that fixed every other furrow irrigation decreased irrigated water at the rate of $26.2 \%$ and then yield at the rate of $11 \%$ and exhibited the highest water use efficiency for biological and grain yields comparing with control. In connection, Kashiani et al. (2011) reported that semialternate furrow irrigation was associated with higher fresh weight of sweet corn compared with all furrow irrigation with no significant differences between semi-alternate furrow irrigation and Every Other Furrow irrigation with $30 \%$ less water supplied.

The most appropriate spacing is one, which enables the plants to make the best use of the conditions at their disposal (Lawson and Topham 1985 and Malik et al. 1993). Reducing row width with a more equidistant planting pattern has the potential to increase maize grain yield especially when highly productive single-cross early hybrids are grown in soils with high fertility and under irrigation (Sangoi et al. 1998). In this sense, Farnham (2001) averaged across years, locations, and plant densities, corn grown on 76-cm row spacing produced higher yields than that grown on 38$\mathrm{cm}$ rows. Maqbool et al.(2006) In Pakistan, found that row spacing $(75,65$ and $55 \mathrm{~cm}$ ) insignificantly affected maize grain yield. Nevertheless, Paszkiewicz,1998 and Roth, 1997 reported maize yield increases of up to $9.9 \%$ by growing maize in rows narrower than $76 \mathrm{~cm}$. In addition, Ahmad (2010) found that narrowing the ridge spacing from 75 to 60 or $45 \mathrm{~cm}$ increased grain yield by $11-18$ and $17-24 \%$, respectively. On saving irrigation water issue, quicker shading of soil surface during early part of the 
season results in less water being lost by evaporation (Karlen and Camp, 1985). This is especially important under favorable soil surface moisture conditions because it allows maize plants to maximize photosynthesis and the proportion of water that is used in growth processes rather than evaporated from the soil. Tsegaye et al.(1993) found that a given amount of water produced about a $10 \%$ higher yield of grain sorghum when applied as wide spaced furrow irrigation (WSFI) than as Every Furrow Irrigation(EFI). The water use efficiency of plants was found to be $24 \%$ higher for WSFI than for EFI and Evaporation from the soil surface was $30 \mathrm{~mm}$ greater for EFI than WSFI. In Egypt, EL-Marsafawy et al. (1998), found that irrigation with $140 \mathrm{~cm}$ apart furrows, compared with $70 \mathrm{~cm}$ apart ones, resulted in $8 \%$ reduction in evapotranspiration and improved root environment, which increased absorption media and encouraged growth characteristics for maize crop.

The objectives of the present study are to find out the extent to which growth, grain yield, yield components, quantities of applied water and water productivity for maize crop were affected due to applying different irrigation patterns under the every other furrow irrigation scheme along with 70 and $80 \mathrm{~cm}$ ridge spacing systems.

\section{MATERIALS AND METHODS}

A Field experiment was conducted at Gemmeiza Agricultural Research Station ( Middle Nile Delta, Egypt ) in 2011 and 2012 to study the effect of different four irrigation patterns under two ridge spacing treatments and their interaction on maize growth, grain yield, yield components, quantity of applied irrigation water and water productivity(WP). Some chemical soil and soil-water characteristics of the experimental site as determined according to klute (1986) and Page et al. (1982) are recorded in Tables 1 and 2. The assessed irrigation patterns were: 1) irrigating all of furrows (control) 2) irrigating via every other furrow technique starting at the $3^{\text {rd }}$ irrigation 3) irrigation via every other furrow technique starting at $4^{\text {th }}$ irrigation 4) irrigating with every other furrow technique starting at $5^{\text {th }}$ irrigation. These irrigation patterns were evaluated under two ridge spacing $(70$ and $80 \mathrm{~cm})$. The experimental design was randomized complete block arranged in incomplete block design, where replications were nested within ridge spacing and irrigation pattern treatments were randomly arranged within ridge spacing treatments. Single Cross 10 maize hybrid was used and the preceding crop was wheat in both seasons. Planting was done on June $6^{\text {th }}$ and $8^{\text {th }}$ in 2011 and 2012 seasons, respectively. Plot size was 6 ridges with $6.8 \mathrm{~m}$ in length for $70-\mathrm{cm}$ ridges spacing with a plot area of $28.6 \mathrm{~m}^{2}$. Meanwhile, it was 6 ridges with $6.0 \mathrm{~m}$ in length for $80-\mathrm{cm}$ ridges spacing giving rise to a plot area of $28.8 \mathrm{~m}^{2}$. Phosphorus and potassium fertilizers at the rate of $15.5 \mathrm{~kg} \mathrm{P}_{2} \mathrm{O}_{5}$ and $24 \mathrm{~kg} \mathrm{~K}_{2} \mathrm{O}$ fad $^{-1}$, respectively, were applied during soil preparation. The experimental field was ploughed twice and properly leveled before sowing to ensure uniform application of water. 
Nitrogen fertilizer (120 kg N fad ${ }^{-1}$ as urea $46.5 \% \mathrm{~N}$ was split into two equal doses and applied before the first and second irrigations. All plants on the $2^{\text {nd }}, 3^{\text {rd }}$ and $4^{\text {th }}$ ridges were harvested and grain yield was adjusted to 15.5 $\%$ moisture and expressed in ardab per feddan (ard fed $\left.{ }^{-1}\right)$. Plants of the fifth ridge were use for sampling, whereas plants of the first and sixth ridges were considered as borders.

Table 1: Some soil chemical properties of the experimental site in 2011 and 2012 seasons.

\begin{tabular}{|l|l|l|}
\hline Soil property & 2011 season & 2012 season \\
\hline Available phosphorus, ppm & 8.5 & 7.8 \\
\hline Available potassium, ppm & 120 & 110 \\
\hline Available nitrogen, ppm & 45.5 & 39.5 \\
\hline Organic matter, \% & 2.37 & 2.50 \\
\hline $\mathrm{pH}(1: 2.5)$ & 7.0 & 7.0 \\
\hline $\mathrm{Ec}, \mathrm{dSm}^{-1}$ & 2.2 & 2.4 \\
\hline
\end{tabular}

Table 2: Some soil - water characteristics of the experimental site

\begin{tabular}{|c|c|c|c|}
\hline $\begin{array}{c}\text { Soil depth } \\
(\mathbf{c m})\end{array}$ & $\begin{array}{c}\text { Field capacity } \\
(\%, \mathbf{w t} / \mathbf{w t})\end{array}$ & $\begin{array}{c}\text { Wilting Point } \\
(\%, \mathbf{w t} / \mathbf{w t})\end{array}$ & $\begin{array}{c}\text { Bulk density } \\
\left(\mathbf{k g m}^{-3}\right)\end{array}$ \\
\hline & \multicolumn{3}{|c|}{$\mathbf{2 0 1 1 \text { season }}$} \\
\hline $00-15$ & 43.20 & 23.40 & 1.11 \\
\hline $15-30$ & 41.00 & 22.24 & 1.26 \\
\hline $30-45$ & 39.60 & 21.52 & 1.31 \\
\hline $45-60$ & 36.00 & 19.57 & 0.82 \\
\hline & \multicolumn{3}{|c}{2012 season } \\
\hline $00-15$ & 45.60 & 24.30 & 1.20 \\
\hline $15-30$ & 42.30 & 22.10 & 1.31 \\
\hline $30-45$ & 39.50 & 21.00 & 1.38 \\
\hline $45-60$ & 36.90 & 18.60 & \\
\hline
\end{tabular}

Growth parameters under study were number of days to $50 \%$ tasseling, number of days to $50 \%$ silking, plant height $(\mathrm{cm})$, ear height $(\mathrm{cm})$, and ear position (\%). Plant height and ear height were measured from the ground surface to the base of the tassel and the base of the upper ear, respectively. Ear position was estimated by dividing ear height by plant height and expressed as percentage.

Grain yield was expressed in ardab per feddan (ard fed $\left.{ }^{-1}\right)$. One ardab $=140 \mathrm{~kg}$ grains $\left(15.5 \%\right.$ moisture content). One feddan $=4200 \mathrm{~m}^{2}$. Tested yield components were ear length $(\mathrm{cm})$, ear diameter $(\mathrm{cm})$, kernel depth $(\mathrm{cm})$, number of kernels per row and 100-kernel weight $(\mathrm{g})$. Data were statistically analyzed according to Steel and Torrie (1980).

\section{Crop-water relationships}

\section{Applied irrigation water}

Irrigation water was applied to the experimental unit through 4" plastic tube and the delivered water was determined according to the following formula: 
$\mathbf{Q}=\mathbf{C A} \sqrt{2 \mathrm{gh}} \quad$ where

$Q=$ discharge rate $\left(\mathrm{cm}^{3} \mathrm{sec}^{-1}\right)$,

$\mathrm{C}=$ discharge coefficient of the spile (which was estimated empirically to be $0.61)$

$\mathrm{g}=$ gravity acceleration $\left(980 \mathrm{~cm} \mathrm{sec}^{-2}\right)$

$\mathrm{A}=$ spile cross sectional area $\left(\mathrm{cm}^{2}\right)$ and

$\mathrm{h}=$ effective water head above the spile $(\mathrm{cm})$

The effective water head above the spile was measured several times during irrigation. Irrigation water was applied to the plot until the propagating wave of in-flowing water reaches the end of the plot. The time required to irrigate the plot was recorded to estimate the amount of water applied.

\section{Water Productivity}

Water productivity (WP), as kg grains per the cubic meter of applied water was estimated as out lined by Molden et al.(2001) as follows:

WP, $\mathbf{k g}$ grain yield $\mathbf{m}^{-3}=$ grain yield, $\mathrm{kg} \mathrm{fad}^{-1} /$ applied water, $\mathrm{m}^{3} \mathrm{fad}^{-1}$.

\section{RESULTS AND DISCUSSION}

\section{Growth, grain yield and yield components}

\subsection{Ridge spacing Effect}

Results revealed that $80-\mathrm{cm}$ ridge spacing significantly decreased both days to $50 \%$ tasseling and $50 \%$ silking in the $1^{\text {st }}$ season, but this effect was not significant for days to $50 \%$ silking in $2^{\text {nd }}$ season (Table 3 ). Plant height was not affected by ridge spacing in both years. Ear height, and ear position (\%) were not significantly affected by ridge spacing in 2011 , but 70 $\mathrm{cm}$ ridge spacing reduced ear height, and ear position (\%) in the $2^{\text {nd }}$ season. In this respect, Zeidan et al. (2006) stated that row spacing exhibited significant effects on number of days from planting to silking. But the present results are contradicted with Ahmad (2010) who reported that plant height was significantly affected by ridge spacing and was higher under $45 \mathrm{~cm}$ ridges spacing than 60 and $75 \mathrm{~cm}$ ones. Such differed trends may be attributed to different experimental situations.

Results revealed that the assessed ridge spacing did not significantly affect grain yield and number of kernels per ear row in both years, and ear length, ear diameter, kernel depth, and 100-kernel weight in 2011 (Table 4). In 2012 , however, $80-\mathrm{cm}$ ridge spacing was associated with significantly higher ear length, ear diameter, kernel depth, and 100-kernel weight. Such findings are in parallel with those reported by Maqbool et al. (2006) and Ahmad (2010). Farnham (2001) averaged across years, locations, and plant densities, stated that maize grown in $76-\mathrm{cm}$ row spacing produced higher yields than that grown in $38-\mathrm{cm}$ rows (10.5 vs. $10.3 \mathrm{Mg} \mathrm{ha}^{-1}$ ), respectively . In addition, Tsegaye et al.(1993) reported that a given amount of water produced about a $10 \%$ higher yield of grain sorghum when applied as Wide Spaced Furrow Irrigation than as Every Furrow Irrigation 
Table 3: Effect of ridge spacing and irrigation pattern on days to $50 \%$ tasseling, days to $50 \%$ sillking, plant height ,ear height and ear position (\%) at Gemmeiza in 2011 and 2012

\begin{tabular}{|c|c|c|c|c|c|}
\hline & $\begin{array}{c}\text { Days to } \\
50 \% \\
\text { tasseling }\end{array}$ & $\begin{array}{c}\text { Days to } \\
50 \% \\
\text { sillking }\end{array}$ & $\begin{array}{c}\text { Plant } \\
\text { height }(\mathrm{cm})\end{array}$ & $\begin{array}{l}\text { Ear height } \\
\quad(\mathrm{cm})\end{array}$ & $\begin{array}{c}\text { Ear } \\
\text { position } \\
(\%)\end{array}$ \\
\hline & \multicolumn{5}{|l|}{2011} \\
\hline \multicolumn{6}{|c|}{ Ridge spacing: } \\
\hline $70 \mathrm{~cm}$ & $62.5 \mathrm{a}$ & $63.5 \mathrm{a}$ & $288 \mathrm{a}$ & $177 \mathrm{a}$ & $61.4 \mathrm{a}$ \\
\hline $80 \mathrm{~cm}$ & $61.9 \mathrm{~b}$ & $62.8 \mathrm{~b}$ & $286 a$ & $174 \mathrm{a}$ & $60.8 \mathrm{a}$ \\
\hline \multicolumn{6}{|c|}{ Irrigation pattern: } \\
\hline$\overline{A L L}$ & $62.1 \mathrm{~b}$ & $63.0 \mathrm{a}$ & $283 \mathrm{~b}$ & $170 \mathrm{a}$ & $60.1 \mathrm{a}$ \\
\hline EOF3 & $62.6 \mathrm{a}$ & $63.4 \mathrm{a}$ & $284 \mathrm{~b}$ & $175 \mathrm{a}$ & $61.5 \mathrm{a}$ \\
\hline EOF4 & $62.3 \mathrm{ab}$ & $63.4 \mathrm{a}$ & $291 \mathrm{a}$ & $180 \mathrm{a}$ & $61.7 \mathrm{a}$ \\
\hline EOF5 & $61.9 \mathrm{~b}$ & $62.9 \mathrm{a}$ & $289 a b$ & $177 \mathrm{a}$ & $61.2 \mathrm{a}$ \\
\hline CV\% & 0.8 & 0.9 & 2.0 & 4.1 & 4.0 \\
\hline & \multicolumn{5}{|l|}{2012} \\
\hline \multicolumn{6}{|c|}{ Ridge spacing } \\
\hline $70 \mathrm{~cm}$ & $60.9 \mathrm{a}$ & $61.8 \mathrm{a}$ & $220 a$ & $122 \mathrm{~b}$ & $55.3 \mathrm{~b}$ \\
\hline $80 \mathrm{~cm}$ & $60.4 \mathrm{~b}$ & $61.5 \mathrm{a}$ & $222 \mathrm{a}$ & $134 \mathrm{a}$ & $60.4 \mathrm{a}$ \\
\hline \multicolumn{6}{|c|}{ Irrigation pattern: } \\
\hline$\overline{A L L}$ & $60.6 \mathrm{a}$ & $61.8 \mathrm{ab}$ & $221 \mathrm{a}$ & $123 \mathrm{~b}$ & $55.5 \mathrm{~b}$ \\
\hline EOF3 & $60.9 \mathrm{a}$ & $61.9 \mathrm{a}$ & $225 \mathrm{a}$ & $134 \mathrm{a}$ & $59.5 \mathrm{a}$ \\
\hline EOF4 & $60.6 \mathrm{a}$ & $61.5 b$ & $227 \mathrm{a}$ & $130 \mathrm{ab}$ & $57.4 \mathrm{ab}$ \\
\hline EOF5 & $60.5 \mathrm{a}$ & $61.5 \mathrm{~b}$ & $211 \mathrm{~b}$ & $125 \mathrm{~b}$ & $59.1 \mathrm{a}$ \\
\hline CV\% & 0.7 & 0.5 & 4.2 & 6.2 & 4.4 \\
\hline
\end{tabular}

${ }^{\dagger}$ Vertical means with the same letter(s) are not significantly different at 0.05 level.

* ALL, EOF3, EOF4 and EOF5 are referred to irrigation all of furrows (control, irrigating via every other furrow technique starting from the $3^{\text {rd }}, 4^{\text {th }}$ and $5^{\text {th }}$ irrigation, respectively.

On the other hand, Alford et al. (2004); Maqbool et al. (2006) and Strieder et al.(2008) found that maize grain yield insignificantly affected due to row spacing. Moreover, Widdicombe and Thelen, 2002; Fanadzo et al. (2010) and Ahmad (2010) found a different trend where narrower ridge spacing out yielded the wider one. Ahmad (2010) found that number of grains per row, cob length and grain weight/ear were significantly affected by ridge spacing. In connection, Maqbool et al. (2006) reported that grain weight/cob was not affected due to 55,65 and $75 \mathrm{~cm}$ row spacing.

\subsection{Irrigation pattern Effect}

Irrigation pattern significantly affected days to $50 \%$ tasseling and plant height in 2011 , days to $50 \%$ silking, plant height, ear height, and ear position in 2012 (Table 3). Irrigation pattern (EOF3) had significantly higher days to $50 \%$ tasseling than the control (ALL) with no significant difference between EOF3 and EOF4 in 2011.

Treatment EOF4 had the highest plant height in 2011 season. In 2012, EOF3 had significantly higher days to $50 \%$ silking compared with EOF4 and EOF5 but the difference between EOF3 and ALL was not significant. The lowest plant height was linked to EOF5 treatment but the highest ear height and ear position resulted from application of EOF3 compared with the control (ALL) in 2012. 
Table 4: Effect of ridge spacing and irrigation patterns on grain yield, ear length, ear diameter, kernel depth, kernels № per row, and 100- kernel weight at Gemmeiza in 2011 and 2012

\begin{tabular}{|c|c|c|c|c|c|c|}
\hline \multirow[t]{2}{*}{ Treatment } & $\begin{array}{c}\text { Grain } \\
\text { yield } \\
(\text { ard fed-1) }\end{array}$ & $\begin{array}{l}\text { Ear length } \\
\text { (cm) }\end{array}$ & $\begin{array}{c}\text { Ear } \\
\text { diameter } \\
(\mathbf{c m})\end{array}$ & $\begin{array}{l}\text { Kernel } \\
\text { depth } \\
\text { (cm) }\end{array}$ & $\begin{array}{c}\text { Kernels } \\
\text { No per } \\
\text { row }\end{array}$ & $\begin{array}{c}100- \\
\text { kernel } \\
\text { weight (g) }\end{array}$ \\
\hline & \multicolumn{6}{|c|}{2011 season } \\
\hline \multicolumn{7}{|c|}{ Ridge spacing: } \\
\hline $70 \mathrm{~cm}$ & $36.6 \mathrm{a}$ & $21.0 \mathrm{a}$ & $4.8 \mathrm{a}$ & $0.91 \mathrm{a}$ & $45.7 \mathrm{a}$ & $44.6 \mathrm{a}$ \\
\hline $80 \mathrm{~cm}$ & $37.8 \mathrm{a}$ & $21.0 \mathrm{a}$ & $4.8 \mathrm{a}$ & $0.91 \mathrm{a}$ & $46.0 \mathrm{a}$ & $44.9 \mathrm{a}$ \\
\hline \multicolumn{7}{|c|}{ Irrigation pattern $^{*}$} \\
\hline ALL & $37.8 \mathrm{a}$ & $21.0 \mathrm{a}$ & $4.73 \mathrm{a}$ & $0.93 \mathrm{a}$ & $46.9 \mathrm{a}$ & $44.9 \mathrm{a}$ \\
\hline EOF3 & $34.5 \mathrm{a}$ & $21.0 \mathrm{a}$ & $4.84 \mathrm{a}$ & $0.93 \mathrm{a}$ & $45.8 \mathrm{ab}$ & $44.8 \mathrm{a}$ \\
\hline EOF4 & $38.1 \mathrm{a}$ & $21.1 \mathrm{a}$ & $4.78 \mathrm{a}$ & $0.89 \mathrm{a}$ & $45.0 \mathrm{~b}$ & $44.6 \mathrm{a}$ \\
\hline EOF5 & $38.1 \mathrm{a}$ & $20.9 \mathrm{a}$ & $4.75 \mathrm{a}$ & $0.90 \mathrm{a}$ & $45.6 \mathrm{~b}$ & $44.8 \mathrm{a}$ \\
\hline CV\% & 8.0 & 1.1 & 5.1 & 14.8 & 2.6 & 1.1 \\
\hline \multicolumn{7}{|c|}{2012 season } \\
\hline \multicolumn{7}{|c|}{ Ridge spacing } \\
\hline $70 \mathrm{~cm}$ & $31.2 \mathrm{a}$ & $20.4 \mathrm{~b}$ & $4.44 \mathrm{~b}$ & $1.05 \mathrm{~b}$ & $44.1 \mathrm{a}$ & $40.8 \mathrm{~b}$ \\
\hline $80 \mathrm{~cm}$ & $31.5 \mathrm{a}$ & $21.7 \mathrm{a}$ & $4.90 \mathrm{a}$ & $1.22 \mathrm{a}$ & $43.1 \mathrm{a}$ & $43.2 \mathrm{a}$ \\
\hline \multicolumn{7}{|c|}{ Irrigation pattern ${ }^{\star}$} \\
\hline ALL & $31.5 \mathrm{a}$ & $21.3 \mathrm{a}$ & $4.75 \mathrm{a}$ & $1.13 \mathrm{a}$ & $44.9 \mathrm{a}$ & $42.3 \mathrm{a}$ \\
\hline EOF3 & $29.7 \mathrm{a}$ & $21.4 \mathrm{a}$ & $4.63 \mathrm{a}$ & $1.15 \mathrm{a}$ & $42.4 \mathrm{a}$ & $42.0 \mathrm{a}$ \\
\hline EOF4 & $31.5 \mathrm{a}$ & $20.8 \mathrm{a}$ & $4.60 \mathrm{a}$ & $1.10 \mathrm{a}$ & $41.7 \mathrm{a}$ & $40.8 \mathrm{a}$ \\
\hline EOF5 & $31.8 \mathrm{a}$ & $20.8 \mathrm{a}$ & $4.70 \mathrm{a}$ & $1.16 \mathrm{a}$ & $45.5 \mathrm{a}$ & $42.9 \mathrm{a}$ \\
\hline CV\% & 7.3 & 4.2 & 4.4 & 10.8 & 13.2 & 5.4 \\
\hline
\end{tabular}

${ }^{\dagger}$ Vertical means with the same letter(s) are not significantly different at 0.05 level.

* ALL, EOF3, EOF4 and EOF5 are referred to irrigation all of furrows (control, irrigating via every other furrow technique starting from the $3^{\text {rd }}, 4^{\text {th }}$ and $5^{\text {th }}$ irrigation, respectively.

Grain yield was not significantly affected by irrigation patterns in the $1^{\text {st }}$ and $2^{\text {nd }}$ seasons (Table 4). In this sense, Rafiee and Shakarami (2010) found that fixed every other furrow irrigation decreased maize grain yield by $11 \%$. Such differed trends may be attributed to different experimental conditions such as timing of treatment application, soil type, maize hybrid, etc. Results in Table 4 revealed that the yield components under study were not significantly influenced by the adopted irrigation patterns, except for kernels per row in 2011. Irrigation patterns EOF4 and EOF5 were associated with the lowest number of kernels per row in 2011.

\subsection{Interaction Effect}

Effect of ridge spacing $x$ irrigation pattern Interaction on ear height was significant in 2011 (Table 5). But this interaction effect was not significant for all other tested traits in 2011 season. In contrast, the effect of ridge spacing $\mathrm{x}$ irrigation pattern interaction was significant for plant height, ear height, and kernel depth in 2012. All other studied traits were not affected by ridge spacing $\mathrm{x}$ irrigation pattern Interaction in 2012.

The highest plant height was associated with application of EOF4 under $70-\mathrm{cm}$ ridge spacing, while the lowest plant height was recorded for EOF5 and ALL in 2012. Under $80-\mathrm{cm}$ ridge spacing, irrigation patterns of EOF3, EOF4, and EOF5 had significantly shorter plant height compared with the control (ALL) in 2012 season. The lowest ear height was achieved 
when maize plants were planted in $70-\mathrm{cm}$ ridge spacing and irrigation pattern (ALL) was followed, and when maize is planted in $80-\mathrm{cm}$ ridge spacing and EOF3 was followed in 2011. In 2012, the lowest ear height was associated with planting in $70-\mathrm{cm}$ ridge spacing when ALL pattern was followed. The longest kernel depth was recorded for maize planting in 80$\mathrm{cm}$ ridge spacing and either EOF4 or EOF3 irrigation regimes were followed in 2012 (Table 5).

Table 5. Effect of ridge spacing (RS) $x$ irrigation pattern (IP) Interaction on plant height, ear height, and kernel depth in 2011 and 2012 seasons.

\begin{tabular}{|l|l|c|c|c|c|c|c|}
\hline \multicolumn{2}{|l|}{ Treatments } & \multicolumn{2}{c|}{ Plant height (cm) } & \multicolumn{2}{c|}{ Ear height (cm) } & \multicolumn{2}{c|}{ Kernel depth (cm) } \\
\hline RS & IP & $\mathbf{2 0 1 1}$ & $\mathbf{2 0 1 2}$ & $\mathbf{2 0 1 1}$ & $\mathbf{2 0 1 2}$ & $\mathbf{2 0 1 1}$ & $\mathbf{2 0 1 2}$ \\
\hline \multirow{4}{*}{$70 \mathrm{~cm}$} & ALL & 284 & 209 & 169 & 109 & 0.93 & 1.08 \\
\cline { 2 - 8 } & EOF3 & 288 & 229 & 183 & 133 & 0.89 & 1.08 \\
\cline { 2 - 8 } & EOF4 & 290 & 235 & 178 & 127 & 0.95 & 0.90 \\
\cline { 2 - 8 } & EOF5 & 290 & 206 & 178 & 118 & 0.88 & 1.15 \\
\hline Mean & 288 & 220 & 177 & 122 & 0.91 & 1.05 \\
\hline \multirow{3}{*}{$80 \mathrm{~cm}$} & ALL & 282 & 234 & 172 & 138 & 0.93 & 1.18 \\
\cline { 2 - 8 } & EOF3 & 281 & 222 & 167 & 135 & 0.98 & 1.23 \\
\cline { 2 - 8 } & EOF4 & 292 & 219 & 182 & 133 & 0.83 & 1.30 \\
\cline { 2 - 8 } & EOF5 & 288 & 215 & 175 & 131 & 0.93 & 1.18 \\
\hline Mean & 286 & 223 & 174 & 134 & 0.92 & 1.22 \\
\hline \multirow{2}{*}{ LSD $_{0.05}$ for } & RS $\times$ IP & NS & 7 & 5 & 6 & NS & 0.09 \\
\hline
\end{tabular}

\section{Crop-water relationships}

\subsection{Applied water}

\subsubsection{Ridge spacing effect}

Results in Table 6 indicate that, regardless of irrigation patterns, applied water decreased under $80 \mathrm{~cm}$ ridge spacing by 7.56 and $7.37 \%$, compared with $70 \mathrm{~cm}$ one in $1^{\text {st }}$ and $2^{\text {nd }}$ seasons, respectively. In connection, Abd El-Halim and Abd El-Razek (2013) stated that, regardless of irrigation intervals, smaller depth of applied water for maize crop was observed with double ridge-furrow planting technique $(140 \mathrm{~cm}$ width) compared to conventional ridged-furrow planting one $(70 \mathrm{~cm}$ width). Moreover, Barbieri et al. (2012) stated that narrow rows consistently increased (8\%) maize crop ET during the initial stages of growth, however, seasonal crop ET was not influenced due to row spacing .

\subsubsection{Irrigation pattern effect}

Regardless ridge spacing, applied irrigation water was reduced under every other furrow irrigation schemes compared with the control (ALL). Application of EOF3, EOF4, and EOF5 irrigation patterns reduced the applied irrigation water by $16.59,12.46$ and $8.22 \%$ in 2011 season and by $16.05,11.39$ and $6.48 \%$ in 2012 season, respectively (Table 6). Several literatures had been cited and confirmed the potency of the other - row irrigation system in reducing the applied irrigation water for maize crop (Abdel-Maksoud and Khater, 1997; Shayannejad and Moharrery, 2009, Mahgoub et al. 2009 and Rafiee and Shakarami, 2010; Kashiani et al. 2011). 


\subsubsection{Interaction Effect}

Interaction effect of ridge spacing $\times$ irrigation pattern revealed that the highest value of applied water was recorded for $70-\mathrm{cm}$ ridge spacing with (ALL) irrigation pattern (control), whereas the lowest value resulted from EOF3 irrigation pattern with $80-\mathrm{cm}$ ridge spacing (Table 6). Such trend was true in $1^{\text {st }}$ and $2^{\text {nd }}$ seasons.

Table 6: Applied water at each irrigation event and seasonal $\left(\mathrm{m}^{3} \mathrm{fad}^{-1}\right)$ under 70 and $80-\mathrm{cm}$ ridge spacing and different irrigation patterns in 2011 and 2012

\begin{tabular}{|c|c|c|c|c|c|c|c|c|}
\hline Ridge spacing & \multicolumn{4}{|l|}{$70 \mathrm{~cm}$} & \multicolumn{4}{|l|}{$80 \mathrm{~cm}$} \\
\hline $\begin{array}{l}\text { Irrigation } \\
\text { pattern* }\end{array}$ & ALL & EOF3 & EOF4 & EOF5 & ALL & EOF3 & EOF4 & EOF5 \\
\hline & \multicolumn{8}{|c|}{2011 season } \\
\hline Planting & 588.8 & 5888 & 588.8 & 588.8 & 556.9 & 556.9 & 556.9 & 556.9 \\
\hline The first & 436.0 & 436.0 & 436.0 & 436.0 & 385.6 & 385.6 & 385.6 & 385.6 \\
\hline The second & 372.1 & 372.1 & 372.1 & 372.1 & 351.5 & 351.5 & 351.5 & 351.5 \\
\hline The third & 346.5 & 230.2 & 346.5 & 346.5 & 317.9 & 231.0 & 317.9 & 317.9 \\
\hline The fourth & 436.0 & 302.8 & 290.2 & 436.0 & 417.1 & 270.5 & 266.3 & 417.1 \\
\hline The fifth & 455.3 & 330.1 & 320.0 & 275.9 & 441.0 & 298.6 & 320.0 & 281.0 \\
\hline The sixth & 346.9 & 280.1 & 290.6 & 286.9 & 336.8 & 198.2 & 226.8 & 260.0 \\
\hline Total, seasonal & 2981.6 & 2540.1 & 2644.2 & 2742.2 & 2806.8 & 2292.3 & 2425.0 & 2570.0 \\
\hline Saving, $\mathrm{m}^{3} \mathrm{fad}^{-1}$ & & 441.5 & 337.4 & 239.4 & & 514.5 & 381.8 & 236.8 \\
\hline \multirow[t]{2}{*}{ Saving, \% } & - & 14.81 & 11.32 & 8.03 & - & 18.33 & 13.60 & 8.44 \\
\hline & \multicolumn{8}{|c|}{2012 season } \\
\hline Planting & 560.3 & 560.3 & 560.3 & 560.3 & 541.0 & 541.0 & 541.0 & 541.0 \\
\hline The first & 410.8 & 410.8 & 410.8 & 410.8 & 365.4 & 365.4 & 365.4 & 365.4 \\
\hline The second & 365.4 & 365.4 & 365.4 & 365.4 & 340.2 & 340.2 & 340.2 & 340.2 \\
\hline The third & 331.0 & 225.1 & 336.0 & 335.6 & 301.6 & 221.3 & 299.9 & 302.8 \\
\hline The fourth & 401.9 & 298.6 & 285.6 & 420.0 & 402.8 & 261.2 & 254.9 & 399.0 \\
\hline The fifth & 436.0 & 318.8 & 301.6 & 266.7 & 430.1 & 320.0 & 301.9 & 275.1 \\
\hline The sixth & 336.0 & 275.1 & 285.2 & 276.8 & 325.9 & 191.1 & 202.4 & 252.0 \\
\hline Total, seasonal & 2728.4 & 2341.1 & 2431.9 & 2522.6 & 2617.0 & 2202.4 & 2305.7 & 2475.5 \\
\hline Saving, $\mathrm{m}^{3} \mathrm{fad}^{-1}$ & - & 443.3 & 296.5 & 205.8 & - & 414.6 & 311.3 & 141.5 \\
\hline Saving, \% & - & 16.25 & 10.87 & 7.54 & - & 15.84 & 11.90 & 5.41 \\
\hline
\end{tabular}

${ }^{*} A L L$, EOF3, EOF4 and EOF5 are referred to irrigation all of furrows (control), irrigating via every other furrow technique starting at the $3^{\text {rd }}, 4^{\text {th }}$ and $5^{\text {th }}$ irrigation, respectively.

\subsection{Water productivity (WP)}

\subsubsection{Ridge spacing effect}

Water productivity is an efficiency term quantified as a ratio of product output (goods and services) over water input. The output could be biological goods such as crop grain, fodder....etc. Data in Table 7 indicated that, regardless the adopted irrigation patterns, water productivity for maize crop, was increased under $80 \mathrm{~cm}$ spacing by 11.70 and $10.24 \%$ in comparison with $70 \mathrm{~cm}$ one, respectively, in $1^{\text {st }}$ and $2^{\text {nd }}$ seasons. In this respect, Tsegaye et al. (1993) found that WUE of sorghum plants was found to be 24\% higher for Wide Spacing Furrow Irrigation than for Every Furrow Irrigation. In addition, Jones (2007) reported that Twin-row spacing as an alternative planting practice for corn silage production in the Shenandoah 
Valley leads to greater corn silage yields through greater water use efficiency and faster canopy development. On the contrary, Barbieri et al.(2012) found that reduced row spacing increased water use efficiency for maize grain production up to $17 \%$.

Table 7: Applied water and water productivity for maize as affected by ridge spacing and Irrigation pattern at Gemmeiza in 2011 and 2012 seasons

\begin{tabular}{|c|c|c|c|c|c|c|c|}
\hline \multirow{2}{*}{\multicolumn{2}{|c|}{ Treatment }} & $\begin{array}{l}\text { Grain } \\
\text { yield } \\
\left(\text { ard fad }^{-1}\right)\end{array}$ & $\begin{array}{l}\text { Applied } \\
\text { Water } \\
\left(\mathbf{m}^{3} \mathrm{fad}^{-1}\right)\end{array}$ & $\begin{array}{l}\text { Water } \\
\text { Productivity } \\
\left(\mathrm{kg} \mathrm{m}^{-3}\right)\end{array}$ & $\begin{array}{l}\text { Grain } \\
\text { yield } \\
\left(\text { ard fad }^{-1}\right)\end{array}$ & $\begin{array}{l}\text { Applied } \\
\text { Water } \\
\left(\mathbf{m}^{3} \mathrm{fad}^{-1}\right)\end{array}$ & $\begin{array}{l}\begin{array}{l}\text { Water } \\
\text { Productivity } \\
\left(\mathrm{kg} \mathrm{m}^{-3}\right)\end{array} \\
\end{array}$ \\
\hline & & \multicolumn{3}{|c|}{2011 season } & \multicolumn{3}{|c|}{2012 season } \\
\hline \multicolumn{8}{|c|}{ Ridge spacing: } \\
\hline \multicolumn{2}{|c|}{$70 \mathrm{~cm}$} & 36.6 & 2727.3 & 1.88 & 31.1 & 2615.1 & 1.66 \\
\hline \multicolumn{2}{|c|}{$80 \mathrm{~cm}$} & 37.8 & 2521.2 & 2.10 & 31.6 & 2422.3 & 1.83 \\
\hline \multicolumn{8}{|c|}{ Irrigation pattern* } \\
\hline \multicolumn{2}{|c|}{ ALL (Control) } & 37.8 & 2894.0 & 1.83 & 31.5 & 2767.0 & 1.59 \\
\hline \multicolumn{2}{|c|}{ EOF3 } & 34.5 & 2416.3 & 2.00 & 29.6 & 2328.1 & 1.79 \\
\hline \multicolumn{2}{|c|}{ EOF4 } & 38.1 & 2530.5 & 2.10 & 31.7 & 2424.7 & 1.82 \\
\hline \multicolumn{2}{|c|}{ EOF5 } & 38.1 & 2656.1 & 2.01 & 32.7 & 2555.1 & 1.79 \\
\hline \multicolumn{8}{|c|}{ Interaction } \\
\hline \multirow{4}{*}{$\begin{array}{l}70 \\
\mathrm{~cm}\end{array}$} & ALL & 36.8 & 2981.6 & 1.73 & 31.5 & 2827.4 & 1.56 \\
\hline & EOF3 & 33.1 & 2540.6 & 1.83 & 29.5 & 2454.1 & 1.68 \\
\hline & EOF4 & 38.3 & 2644.7 & 2.03 & 30.4 & 2543.9 & 1.67 \\
\hline & EOF5 & 38.0 & 2742.2 & 1.94 & 33.1 & 2635.1 & 1.76 \\
\hline \multirow{4}{*}{$\begin{array}{l}80 \\
\mathrm{~cm}\end{array}$} & ALL & 38.7 & 2806.4 & 1.93 & 31.5 & 2706.5 & 1.63 \\
\hline & EOF3 & 36.1 & 2291.9 & 2.21 & 29.7 & 2202.1 & 1.89 \\
\hline & EOF4 & 38.0 & 2416.3 & 2.19 & 32.9 & 2305.4 & 2.00 \\
\hline & EOF5 & 38.2 & 2570.0 & 2.08 & 32.2 & 2475.1 & 1.82 \\
\hline
\end{tabular}

* ALL, EOF3, EOF4 and EOF5 are referred to irrigation all of furrows (control), irrigating via every other furrow technique starting at $3^{\text {rd }}, 4^{\text {th }}$ and $5^{\text {th }}$ irrigation, respectively

\subsubsection{Irrigation pattern effect}

Applied irrigation water was efficiently utilized where EOF irrigation patterns were applied, compared with the control (Table 7). Application of irrigation patterns EOF3, EOF4, and EOF5 improved water productivity (WP) by $9.29,14.75$ and $9.84 \%$ in the $1^{\text {st }}$ season and $12.58,14.47,12.58 \%$ in $2^{\text {nd }}$ season compared with the control (ALL), respectively. Results of the $2^{\text {nd }}$ year followed similar pattern to the first year, which confirmed the potency of EOF technique in improving WP. The role of EOF irrigation scheme in enhancing water use efficiency for maize crop was previously reported by Shayannejad and Moharrery (2009) and Rafiee and Shakarami (2010). In connection, Kang et al. (2000a and 2000b) stated that controlled alternate partial root-zone irrigation (part of the root system being exposed to drying soil while the remaining part being irrigated normally) are also ways to increase WUE of maize.

\subsubsection{Interaction Effect}

The interaction data in Table 7 indicated that higher WP figures were recorded under EOF3 and EOF4 irrigation patterns as interacted with $80 \mathrm{~cm}$ ridge spacing and such findings were true in $1^{\text {st }}$ and $2^{\text {nd }}$ seasons.

On conclusion, as well known that under limited irrigation water resources, it's recommended to point out how much water, based on either 
consumed or applied, required to produce the unity of final crop yield which is defined as water productivity. On this basis and according to data in Table 7, it is advisable to cultivate maize crop on $80 \mathrm{~cm}$ ridge space and irrigating according to EOF3 or EOF4 irrigation regimes where such interactions exhibited acceptable values of water saving, WP and grain yield under the experimental circumstances. Further researches are needed to confirm the achieved results.

\section{REFERENCES}

Abd El-Halim, A. A. and U. A. Abd El-Razek (2013). Effect of different irrigation intervals on water saving, water productivity and grain yield of maize (Zea mays L.) under the double ridge-furrow planting technique. Archives of Agronomy and Soil Science. In press.

Abdel-Maksoud, H. H. and A. N. Khater (1997). Improving surface irrigation performance through the other-row and surge irrigation techniques. Misr J. Ag. Eng. 14(2):170-180.

Ahmad, M. (2010). Influence of ridge spacing and plant density on productivity of different maize hybrids. PhD thesis, Faculty of Agric., Univ. of Agric., Faisalabad - Pakistan.

Alford, C. M.; D. Stephen; Miller and J.T. Cecil (2004). Using row spacing to increase crop competition with weeds. Proc. 4th Int. Crop Sci. Cong., Birsbane, Australia.

Barbieri, P., L. Echarte; A. Della Maggiora; V. O. Sadras; H. Echeverria and F. H. Andrade (2012). Maize Evapotranspiration and Water-Use Efficiency in Response to Row Spacing. Agron. J., 104(4):939 - 944.

EL-Marsafawy, Samia M.; A.Y Salib; M.A. Aly and H.M. Eid (1998). Row width and nitrogen levels impacts on water relations, growth and yield of maize crop. Third Conference of Meteorology and Sustainable development Cairo, Egypt.

Fanadzo, M.; C.Chiduza and P.N.S. Mnkeni (2010). Effect of inter-row spacing and plant population on weed dynamics and maize (Zea mays L.) yield at Zanyokwe irrigation scheme, Eastern Cape, South Africa. African J.of Agric. Res., Vol. 5(7): 518-523.

Farnham, D. E. (2001). Row Spacing, Plant Density, and Hybrid Effects on Corn Grain Yield and Moisture. Agron. J., Vol. 93 No. 5: 1049-1053.

Jones, P. B. (2007). Effects of Twin-Row Spacing on corn silage growth development and yield in the.cses.vt.edu/ Shenandoah Valley. http://www.valley crops 2009 Crop Management Assets. (cited from Greener J. of Agric. Sci., Vol. 2 (4): 108 -129, August 2012.

Kang, Shaozhong ;Zongsuo Liang ;Yinhua Pan ;Peize Shi and Jianhua Zhang (2000a). Alternate furrow irrigation for maize production in an arid area. Agric. Water Management, Vol 45, Issue 3 : 267-274

Kang, Shaozhong ; Wenjuan Shi and Jianhua Zhang (2000b). An improved water-use efficiency for maize grown under regulated deficit irrigation. Field Crop Res., Vol 67, Issue 3 : 207-214. 
Karlen D.L. and C.R. Camp (1985). Row Spacing, plant population and water management effects on corn in the Atlantic coastal plain. Agron.J., 77:393-398.

Kashiani, P., G.Saleh, M. Osman, and D. Habibi (2011). Sweet corn yield response to alternate furrow irrigation methods under different planting densities in a semiarid climatic condition. Afr. J. Agric. Res. 6(4): $1032-1040$.

Klute, A. (1986). Methods of Soil Analysis. Part 1. 2nd ed. ASA and SSSA. Madison, Wisconsin, USA.

Lawson, H. M and P.B. Topham (1985). Competition between annual weeds and vining peas grown at a range of population densities: effects on the weeds. Weed Res., 25: 221-229.

Mahgoub, G. M. A., M. E. M. Abd E. Azeem, Hoda, Kh. A El_Mekser, and M. M. Ewis (2009). Effect of different irrigation patterns on water consumption, water use efficiency, and grain yield of maize. Egypt. J. of Appl. Sci., 24(10B) 518-530.

Malik, V.S., C.J. Swanton and T.E. Michaels.(1993). Interaction of white bean (Phaseolus vulgaris) cultivars, row spacing and seeding density with annual weeds. Weed Science, 41: 62-68.

Maqbool, M.M.; A. Tanveer; Z. Ata and R. Ahmad (2006). Growth and yield of maize (Zea mays L) as affected by row spacing and weed competition durations. Pak. J. Bot., 38(4): 1227-1236.

Molden, D.; H. Murray-Rust,; R. Sakthivadivel and I. Makin (2001). A water productivity framework for understanding and action. Workshop on Water productivity. Wadduwa,Sri Lanka, November 12 and 13, 2001.

Page, A.L.; R.H. Miller and D.R. Keeney (1982)."Methods of Soil Analysis" Part 2.Amer. Soc. Agron., Madison, Wisconsin, USA

Paszkiewicz, S. (1998). Narrow row width influence on corn yield. p.1. In I. Pioneer Hi-plant density in Eastern Nebraska. Agron. J. 98: 529-535.

Rafiee, M. and Shakarami, G. (2010). Water use efficiency of corn as affected by every other furrow irrigation and planting density. World Appl. Sci. J., 11 (7): 826-829.

Roth, G.W. (1997). Potential of narrow row corn production in Pennsylvania. Pennsylvania State Univ. Agron. Fact 52.

Sangoi, L., M. Ender and A. Merotto Jr. (1998). Dominância apical de híbridos de milho de diferentes épocas em três densidades de semeadura. In: Reunião Anual Do Milho E Sorgo, 42, 1997. Erechim, RS. Anais. Erechim; Cotrel/Emater/Fepagro. 382. pp.31-36.

Shayannejad, M. and A. Moharrery (2009). Effect of every-other furrow irrigation on water use efficiency, starch and protein contents of potato. J. Agric. Sci., 1(2) : 107-11r.

Steel, R. G. D. and J. H. Torrie (1980). Principles and procedures of statistics, $2^{\text {nd }}$. Ed. McGraw. Co., New York, USA.

Strieder ,Mércio Luiz; Paulo Regis Ferreira da Silva; Lisandro Rambo; Luís Sangoi; Adriano Alves da Silva; Paulo César Endrigo and Douglas Batista Jandrey (2008). Crop management systems and maize grain yield under narrow row spacing. Sci. Agric. (Piracicaba, Braz.), Vol. 65:346 - 353 
Tsegaye, Teferi; J.F. Stone and H. E. Reeves (1993). Water Use Characteristics of Wide-Spaced Furrow Irrigation. Soil Sci. Soc. of American J., Vol. 57 No. 1: 240-245.

Widdicombe, W. D. and K.D. Thelen (2002). Row Width and Plant Density Effects on Corn Grain Production in the Northern Corn Belt. Agron. J., 94:1020-1023.

Zeidan, M.S., A.B. Amany and M.F. El-Kramany (2006). Effect of N-fertilizer and plant density on yield and quality of maize in sandy soils. Res. J. Agric. Bio. Sci. 2(4):156-161.

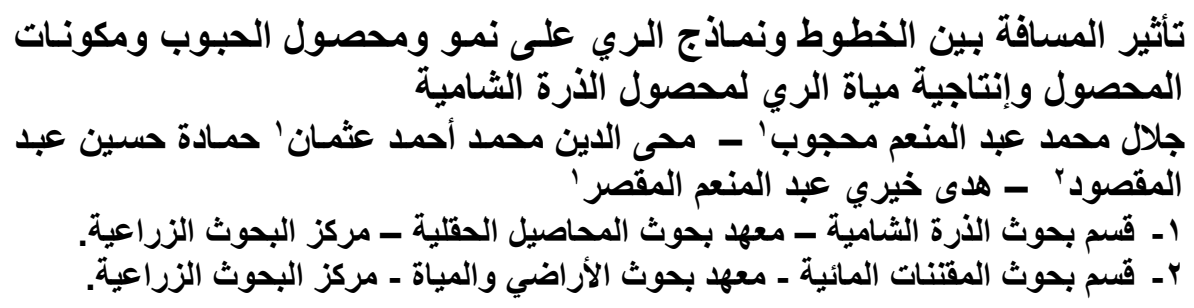

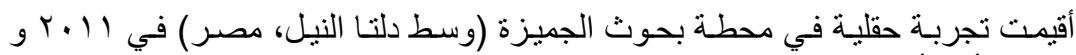

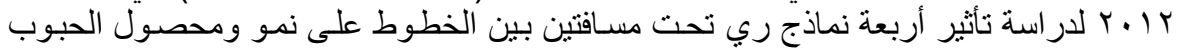

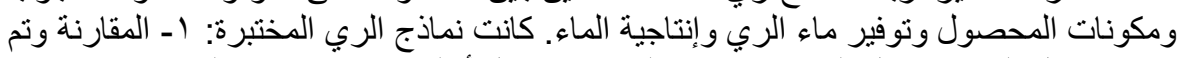

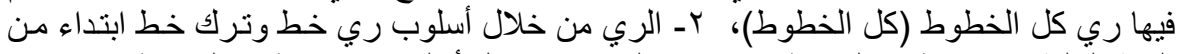

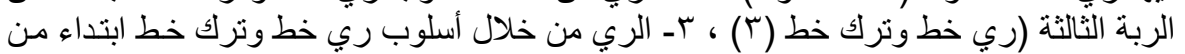

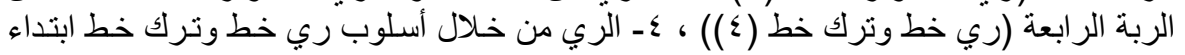

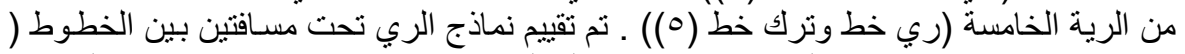

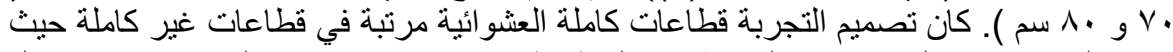

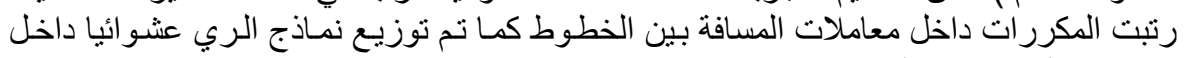
معاملات المسافة بين الخطوط.

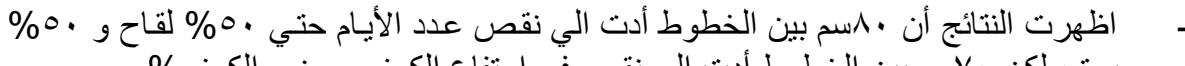

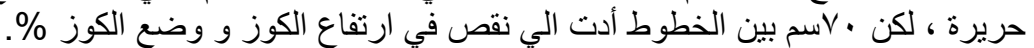

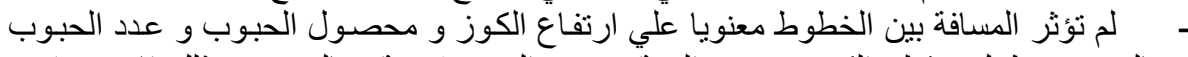

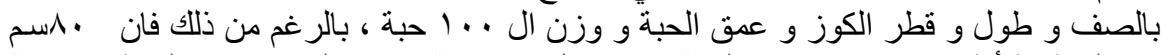

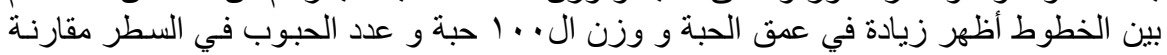

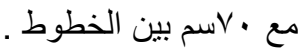

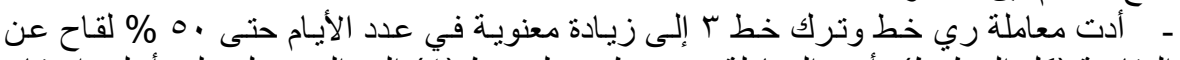

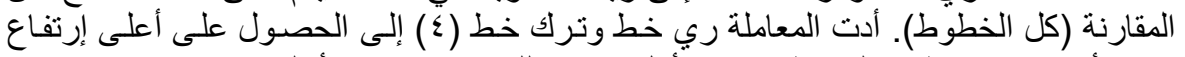

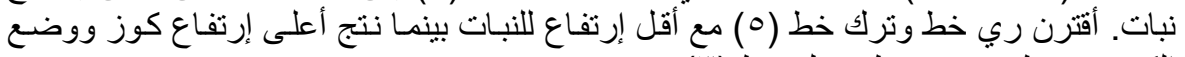

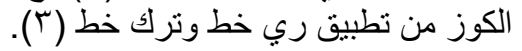

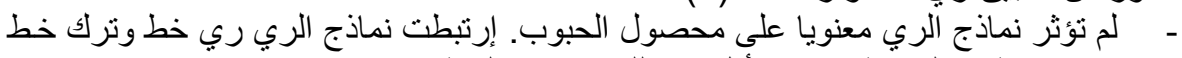

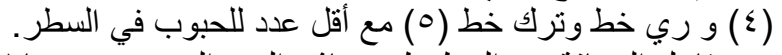

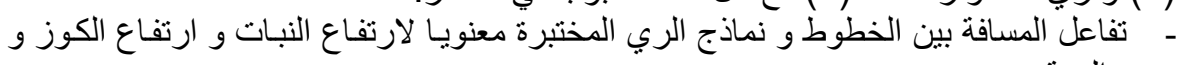

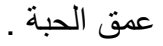

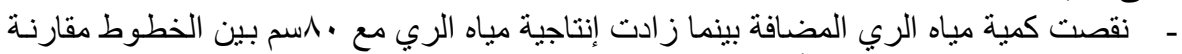

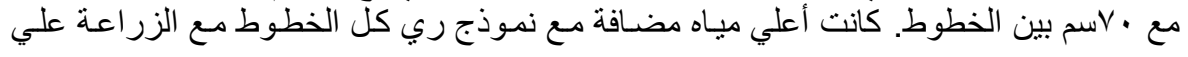


Mahgoub, G. M. A. et al.

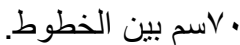

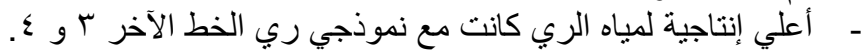

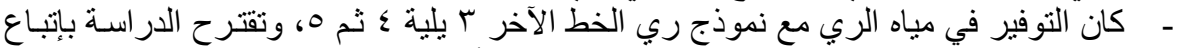

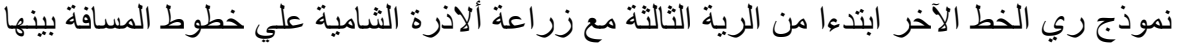
1 م سم نظر التوفير مياة الري دون نقص في محصول الحبوب.

كلية الزراعة - جامعة المنصورة مركز البحوث الزراعية
قام بتحكيم البحث إند المر

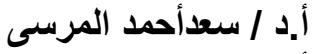

أ.د / محمد عبد الفتاح ابراهيم 